\title{
MACROECONOMIC EFFECTS OF THE ECB'S FORWARD GUIDANCE
}

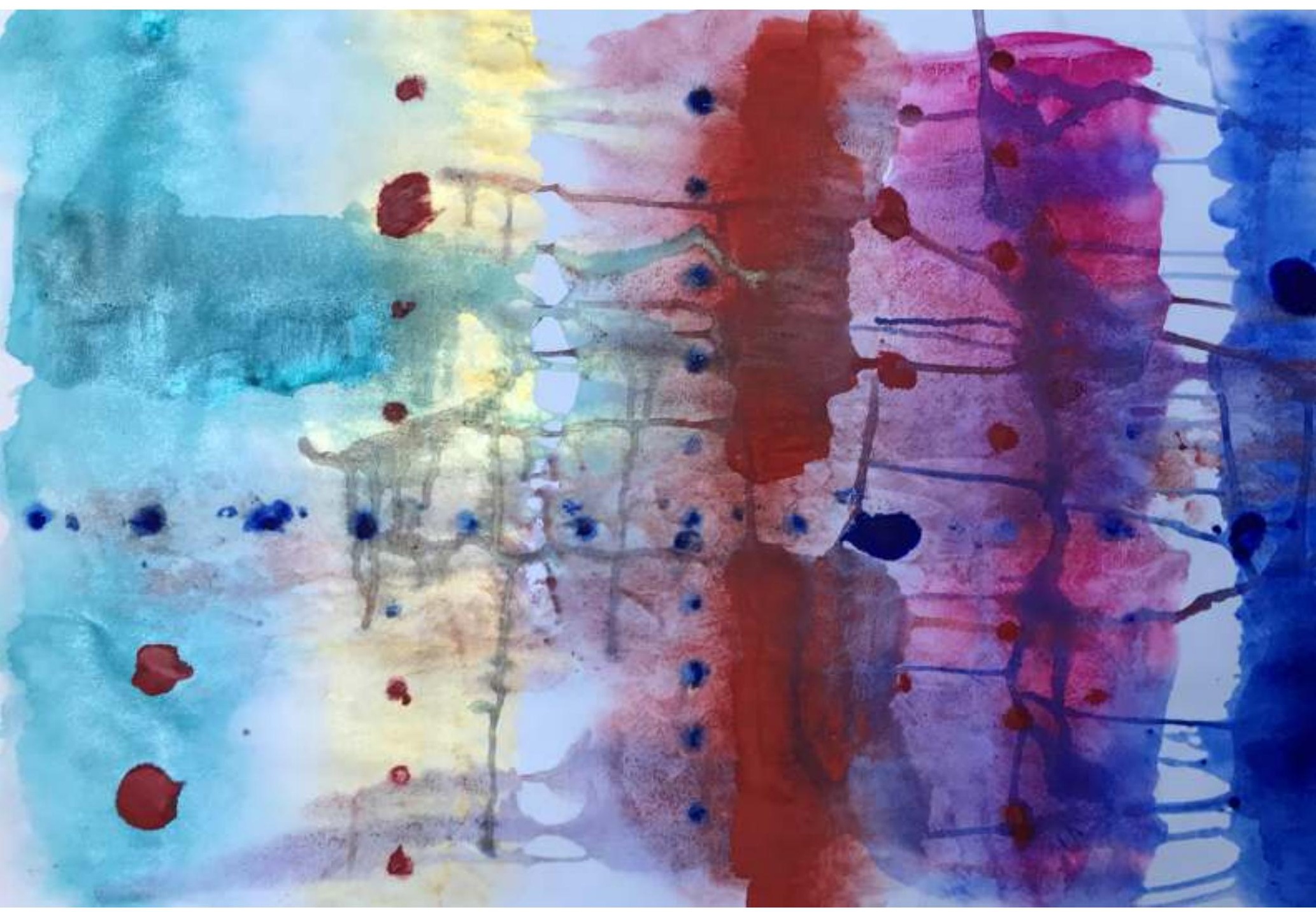




\section{CONTENTS}

ABSTRACT 3

1. INTRODUCTION 4

2. ECONOMETRIC FRAMEWORK

3. RESULTS 9

4. SENSITIVITY ANALYSIS 13

CONCLUSIONS 16

$\begin{array}{ll}\text { APPENDIX } & 17\end{array}$

$\begin{array}{ll}\text { A.1 Dataset description and transformations } & 17\end{array}$

$\begin{array}{ll}\text { A.2 Event study } & 18\end{array}$

$\begin{array}{ll}\text { BIBLIOGRAPHY } & 20\end{array}$

APP - expanded asset purchase programme

AR - autoregressive

BIS - Bank for International Settlements

bp - basis point

CISS - Composite Indicator of Systemic Stress

DSGE - dynamic stochastic general equilibrium

ECB - European Central Bank

ELB - effective lower bound

EUR - euro

Eurostat - Statistical Office of the European Union

FG - forward guidance

GDP - gross domestic product

HICP - Harmonised Index of Consumer Prices

MRO - main refinancing operation

NPISH - non-profit institution serving households

SPF - Survey of Professional Forecasters

SV - stochastic volatility

SVAR - structural vector autoregression

TVP-SVAR - time-varying parameter structural vector autoregression

TVP-SVAR-SV - time-varying parameter structural vector autoregression with stochastic volatility

US - United States of America

USD - US dollar

VAR - vector autoregression

vs - versus

YOY - year-on-year 


\section{ABSTRACT}

This paper empirically evaluates the macroeconomic effects of the European Central Bank's (ECB) forward guidance (FG) on the euro area economy and analyses its interaction with asset purchases. To that end, we employ a battery of structural vector autoregressions (SVARs) with both constant and time-varying parameters and/or the error covariance matrix to explore the propagation of the FG shock over time and account for the changing nature of the ECB's FG (Odyssean since July 2013, Delphic prior to that). The FG shock is identified via both traditional sign and zero restrictions of Arias et al. (2014) and narrative sign restrictions of Antolin-Diaz and RubioRamírez (2018) which allow us to incorporate additional information about the timing of the shock to sharpen the inference. We find that the ECB's FG on interest rates has been an effective policy tool as its announcement causing a 5 bps drop in interest rate expectations increases output by $0.09 \%-0.12 \%$ and the price level by $0.035 \%$. In addition, multiple evidence suggests that the introduction of the expanded asset purchase programme (APP) in 2015 considerably enhanced the FG credibility. Regarding the transmission mechanism, we find that FG significantly lowered uncertainty in the euro area as well as borrowing costs for both households and firms.

Key words: forward guidance, central bank communication, unconventional monetary policy, euro area, structural VAR

JEL codes: C54, E32, E52, E58

The author would like to thank participants of an internal seminar held at Latvijas Banka for useful suggestions and Erlands Krongorns (Latvijas Banka) for excellent research assistance. Comments by reviewers Boriss Siliverstovs (Latvijas Banka) and Lenno Uusküla (Eesti Pank) are gratefully acknowledged.

The views expressed in this paper are those of the author and do not necessarily reflect the views of Latvijas Banka.

Andrejs Zlobins: Latvijas Banka, K. Valdemāra iela 2A, Riga, LV-1050, Latvia; e-mail: Andrejs.Zlobins@bank.lv. 


\section{INTRODUCTION}

Since the beginning of the Great Recession, central banks in advanced economies resorted to several non-standard monetary policy measures because policy rates approached the ELB and were no longer an effective measure to sufficiently increase inflation towards the target. In addition to outright asset purchases or quantitative easing, central banks began to provide FG on the future path of policy rates, essentially using central bank communication as policy tool to manage expectations of economic agents. The ECB has been providing FG on interest rates since July 2013; however, FG has acquired a more significant role in signalling the monetary policy stance since the end of net asset purchases under the APP in December 2018.

There is a vast literature documenting the overall experience with FG in the countries whose central banks have provided some information or commitment concerning the future path of policy rates (see Moessner et al. (2017) for extensive literature survey). Campbell et al. (2012), along with Moessner (2013; 2015), Woodford (2013) and D'Amico and King (2015), have studied the FG provided by the Federal Reserve System in the US, concluding that it has been an effective monetary policy measure. This sentiment is also echoed in the survey of central bank governors and academics by Blinder et al. (2017). Campbell et al. (2012) also suggest to distinguish between Delphic and Odyssean FG. Delphic FG is referred to a situation when the central bank provides a macroeconomic forecast, including a future policy rate path, but stresses that it is conditional on the actual macroeconomic outcomes. While in the case of Odyssean FG the central bank commits to the communicated policy path regardless of the actual macroeconomic performance. Theoretical findings of Adam and Billi $(2006 ; 2007)$ and Nakov $(2008)$ suggest that Odyssean FG is more effective and this also backed by empirical evidence of Andrade and Ferroni (2018).

Several empirical papers have focused on assessing the effects of the ECB's FG, with Coenen et al. (2017) and Altavilla et al. (2019) providing the evidence on financial market impact, while Andrade and Ferroni (2018) and Jarociński and Karadi (2018) trace out the macroeconomic implications of FG in the euro area. Both papers use a two-step procedure to pin down the FG macroeconomic impact: they use variations in high frequency financial data around the policy announcements to capture the FG shock and then instrument the reduced form VAR residuals with the obtained shock series similarly to Stock and Watson (2012) and Mertens and Ravn (2013), i.e. the proxy SVAR approach. However, D'Amico and King (2015), using US data, show that it is possible to capture the FG shock in a single step by employing VAR augmented with survey data on expectations. This approach has also been applied to the euro area data by Christoffel et al. (2018). While these studies have found that the ECB's FG has been an effective policy tool, only a few papers have studied the interaction of FG with asset purchases. Some evidence can be found in Coenen et al. (2017) and Altavilla et al. (2019), which show that the APP considerably enhanced the FG credibility, but they strictly focus on financial market impact.

We expand the empirical literature on the ECB's FG by studying the macroeconomic implications of FG when it is used in conjunction with asset purchases. Additionally, Andrade and Ferroni (2018) show that the FG effects have considerably changed in the euro area over time, i.e. ECB monetary policy announcements have been mainly Odyssean in their nature since FG was officially adopted in July 2013 and Delphic prior to that. This motivates us to employ a battery of SVARs with both constant and 
time-varying parameters and/or the error covariance matrix to explore the propagation of the FG shock over time and account for the changing nature of the ECB's FG. Our identification strategy is similar to that of D'Amico and King (2015), but we choose to use a market-based measure of interest rate expectations instead of a survey-based measure, mainly for practical reasons, as it allows us to estimate the models with monthly data. In addition to using traditional sign and zero restrictions of Arias et al. (2014), we also employ narrative sign restrictions of Antolin-Diaz and Rubio-Ramírez (2018), which, to the best of our knowledge, is the first application of this methodology in the empirical literature on FG.

To sum up, we expand the literature on the ECB's FG in several directions: first, we identify the FG shock in a single step, using SVAR with a market-based measure of interest rate expectations instead of a survey-based measure. Second, we combine the flexibility of a single-step approach with the sharp identification of a two-step procedure by utilising the narrative sign restrictions of Antolin-Diaz and RubioRamírez (2018). Third, we study the macroeconomic effectiveness of FG when it is complemented with asset purchases. Finally, we assess the FG impact in a timevarying parameter framework given the changing perception of the ECB's FG over time by economic agents.

The paper is organised as follows. Section 2 describes the econometric models, data and identification strategy used to measure the FG impact. Section 3 presents the results and discusses the transmission mechanism, while Section 4 is devoted to robustness checks of our estimates. Finally, Section 5 concludes.

\section{ECONOMETRIC FRAMEWORK}

Most papers, which empirically assess the macroeconomic effectiveness of FG, employ SVARs with constant parameters and the covariance matrix as well as the identification via sign restrictions. We follow a similar econometric strategy in this paper, but in addition, we also consider extensions with time-varying parameters and/or the error covariance matrix given that the existing evidence suggests that the perception of the ECB's FG has changed over time, particularly since July 2013 when the ECB started using it as fully-fledged policy tool. In total, we use three different SVARs: a model with constant parameters and volatility, a model with constant parameters but with SV and a model with time-varying parameters and volatility.

We start our analysis by considering a standard SVAR model with constant parameters and the error covariance matrix:

$$
A_{0} x_{t}=a_{0}+\sum_{j=1}^{p} A_{j} x_{t-j}+\varepsilon_{t}
$$

where $a_{0}$ is a vector of constants, $A_{j}$ is an $m \times m$ array of coefficients, $x_{t}$ for $t=1, \ldots, T$ is an $m \times 1$ vector of $m$ variables and $\varepsilon_{t}$ is an $m \times 1$ vector of residuals with variancecovariance matrix $\Sigma_{t}$. We choose to estimate our model with Bayesian methods by specifying a standard Minnesota prior distribution. We specify the prior using standard values for the hyper-parameters following Dieppe et al. (2016), i.e. we set the AR coefficient of the prior to 0.8 , overall tightness $\lambda_{1}=0.1$, cross-variable weighting $\lambda_{2}=0.5$, lag decay $\lambda_{3}=1$ and exogenous variable tightness $\lambda_{4}=100$. 
We estimate the model with data covering the period from January 2009 to December 2018 to minimize the vulnerability to the Lucas critique. The motivation behind this is that we want to explore the interaction of FG with asset purchases, but the ECB only started to use unconventional balance sheet-based instruments in the aftermath of the Great Recession. Thus, estimating the model with the data prior to that could lead to biased estimates of the FG macroeconomic impact.

In addition, given that the sample includes several episodes of severe economic volatility, it is useful to also consider a model with the time-varying error covariance matrix, i.e. stochastic volatility:

$\Sigma_{i, t}=F \Lambda_{t} F^{\prime}$

where $F$ is a lower triangular matrix with a unit diagonal and $\Lambda_{t}$ is a diagonal matrix of log-volatilities denoted by $\lambda_{i, t}$ which follow the AR(1) process:

$\lambda_{i, t}=\gamma_{i} \lambda_{i, t-1}+v_{i, t} \quad v_{i, t} \sim N\left(0, \phi_{i}\right)$

where $\gamma_{i}$ is a variable-specific persistence parameter and $v_{i, t}$ is a white noise error. However, contrary to the standard approach of Cogley and Sargent (2005) to modelling SV, who do not estimate the persistence parameter $\gamma$, we treat $\gamma_{i}$ to be a variable-specific endogenous variable which is estimated from the data as in Dieppe et al. (2016) who generalise the approach of Jacquier et al. (1994) to multivariate models. The estimation of $\gamma_{i}$ also requires to set a prior distribution for it. Following Jacquier et al. (1994), we assume that it follows a normal distribution:

$\pi\left(\gamma_{i}\right) \sim N\left(\gamma_{0}, \zeta_{0}\right)$

In order to let the data speak, we make the prior on $\gamma_{i}$ non-informative by setting the prior mean $\gamma_{0}=0$ with large variance $\zeta_{0}=1000$. For other coefficients, the prior distribution follows the standard Minnesota scheme with identical hyperparametrisation to a model with constant volatility.

Finally, we introduce time variation in the SVAR coefficients along the lines of Primiceri (2005) and Gambetti and Musso (2017). For convenience, suppose that we stack matrices of SVAR coefficients from equation 1 into vector $\theta_{t}=\left(a_{0}^{\prime}, \operatorname{vec}\left(\mathrm{A}_{j}\right)^{\prime}\right)$. The time variation of coefficients is then modelled as random walk process:

$\theta_{t}=\theta_{t-1}+v_{t} \quad v_{t} \sim N(0, \Omega)$

However, given the large computational costs involved in the estimation of this model, stochastic volatility is modelled following Cogley and Sargent (2005); this simplification is also used in TVP-VARs by Primiceri (2005) and Gambetti and Musso (2017):

$\Sigma_{i, t}=F \Lambda_{t} F^{\prime}$

$\lambda_{i, t}=\gamma \lambda_{i, t-1}+v_{i, t} \quad v_{i, t} \sim N\left(0, \phi_{i}\right)$

In this case, the persistence parameter $\gamma$ is not estimated; it is set to 0.85 for every variable included in the model. Following Dieppe et al. (2016), we make the assumptions about the prior distribution in our TVP-SVAR-SV set out below: 
$\pi(\theta \mid \Omega) \sim N\left(0, \Omega_{0}\right)$

$f_{i}^{-1} \sim N\left(f_{i 0}^{-1}, \Upsilon_{i 0}\right)$

$\pi\left(\lambda_{i} \mid \phi_{i}\right) \sim N\left(0, \phi_{0}\right)$

$\pi\left(\omega_{i}\right) \sim I G\left(\frac{\chi_{0}}{2}, \frac{\psi_{0}}{2}\right)$

$\pi\left(\phi_{i}\right) \sim I G\left(\frac{\alpha_{0}}{2}, \frac{\delta_{0}}{2}\right)$

where $f_{i}^{-1}$ denotes the vector in the $F$ matrix containing the non-zero and non-one elements with mean $f_{i 0}^{-1}$ and covariance $\Upsilon_{i 0}, \omega_{i}$ are diagonal entries in the $\Omega$ matrix with the $\chi_{0}$ and $\psi_{0}$ denoting the hyperparameters governing the shape and scale of variance. In order to make the prior non-informative, we set $\chi_{0}=\psi_{0}=0.001$. Similarly, $\alpha_{0}$ and $\delta_{0}$ are hyperparameters related to the variance of volatility which are set to $\alpha_{0}=\delta_{0}=0.001$.

The advantage of this framework over other non-linear VARs, e.g. Markov-switching or threshold VARs, lies in agnosticism towards possible structural changes in the sample considered as it does not require to set a specific number of regimes ex ante. This property is particularly appealing for the euro area as it has been hit by severe economic shocks (the Great Recession and sovereign debt crisis) as well as the change in the monetary policy regime (the introduction of several unconventional tools due to the ELB) which can potentially lead to significant but uncertain structural changes in the economy and policy rules.

In the benchmark specification, all three models include six monthly variables: output, the price level, the exchange rate, equity prices, the short-term interest rate and its expectations. We use 1-year forward rate of 3-month EURIBOR as our main measure of interest rate expectations in the euro area. Correspondingly, we use 3-month EURIBOR as a proxy for the policy rate. Our choice of using a market-based measure instead of a survey-based measure (e.g. interest rate forecasts from the SPF) is based on practical grounds since it allows us to estimate the models with monthly data, while survey-based expectations are only available at quarterly frequency. Nonetheless, we also run a robustness check, using SPF interest rate forecasts. Variables are included in the models as levels with the exception of TVP-SVAR-SV, which requires the variables to be stationary, otherwise this type of model would exhibit explosive behaviour. See Appendix A.1 for a detailed information on data transformations. The lag order in all three models is set to 2 .

In order to identify the FG shock, we employ the sign and zero restrictions approach of Arias et al. (2014) as our baseline approach. Nonetheless, we also make use of the narrative sign restrictions of Antolin-Diaz and Rubio-Ramírez (2018) which extends the approach developed in Rubio-Ramírez et al. (2010) and Arias et al. (2014) by constraining the structural shocks identified via sign restrictions with additional information about the timing of the shock, thus creating an alternative to the proxy SVAR approach employed by Andrade and Ferroni (2018) and Jarociński and Karadi (2018). The advantage of the narrative sign restrictions is that the shocks can be directly identified within the VAR, thus minimizing the measurement error in comparison to a case when the narrative time series is constructed outside the model. 
A summary of our baseline identifying restrictions is provided in Table 1. As discussed in Altavilla et al. (2019), based on the evidence from Andrade and Ferroni (2018) and Jarociński and Karadi (2018), FG can have opposite effects on stock prices, which, in turn, determines the macroeconomic outcomes. For example, if FG is interpreted as Delphic, i.e. if the information shock prevails, it will have a negative impact on stock prices because a central bank, when promising lower rates for a longer period, also reveals information that the business cycle is weaker than expected, thus signalling lower dividends. But in the case when a pure policy surprise dominates, i.e. the central bank announcement is perceived as Odyssean, FG will have positive effects on stock valuations because lower short-term interest rates increase aggregate demand and lower discount rates. Since the existing empirical literature finds that only Odyssean FG generates macroeconomic effects and that this type of FG shock has dominated since the ECB officially started to provide guidance on the future interest rate path in July 2013, our identification strategy is aimed at disentangling the Odyssean FG shock. Restrictions on output and prices are imposed to hold in the third month after the shock, while other restrictions - on impact and two months after the shock.

Table 1

Baseline identification restrictions

\begin{tabular}{|c|c|c|c|c|c|c|}
\hline Shock & $\begin{array}{l}\text { Real } \\
\text { GDP }\end{array}$ & $\begin{array}{l}\text { Core } \\
\text { HICP }\end{array}$ & $\begin{array}{l}\text { 3-month } \\
\text { EURIBOR }\end{array}$ & $\begin{array}{c}\text { 3-month } \\
\text { EURIBOR } \\
\text { 1-year forward rate }\end{array}$ & EUR/USD & $\begin{array}{c}\text { Dow Jones } \\
\text { Euro } \\
\text { Stoxx } 50\end{array}$ \\
\hline Monetary policy & + & + & - & & - & + \\
\hline $\mathrm{FG}$ & + & + & 0 & - & - & + \\
\hline
\end{tabular}

The identifying restrictions used when we augment the standard sign restrictions with narrative information are shown in Table 2. In this paper we only use "Type I restrictions", following the term used in Antolin-Diaz and Rubio-Ramírez (2018), which only imposes narrative information about the sign of the shock in certain period. We impose a single narrative sign restriction to identify the FG shock.

Narrative Sign Restriction I. The FG shock must take negative value in July 2013, i.e. when the policy was first officially announced.

Table 2

Identification restrictions used with narrative information

\begin{tabular}{|c|c|c|c|c|c|c|}
\hline Shock & $\begin{array}{l}\text { Real } \\
\text { GDP }\end{array}$ & $\begin{array}{l}\text { Core } \\
\text { HICP }\end{array}$ & $\begin{array}{l}\text { 3-month } \\
\text { EURIBOR }\end{array}$ & $\begin{array}{c}\text { 3-month } \\
\text { EURIBOR } \\
\text { 1-year forward rate }\end{array}$ & EUR/USD & $\begin{array}{c}\text { Dow Jones } \\
\text { Euro } \\
\text { Stoxx } 50\end{array}$ \\
\hline Monetary policy & & & - & & - & + \\
\hline $\mathrm{FG}$ & & & 0 & - & - & + \\
\hline
\end{tabular}

As shown in Table 2, the use of narrative information allows us to remain agnostic about the FG impact on real economy. This aspect of identification will be more thoroughly discussed in the sensitivity analysis section.

Finally, since one of our aims is to explore the interaction of FG with asset purchases, we expand the baseline model with two additional variables, i.e. long-term interest rates and the ECB asset holdings, and identify the APP shock. This also serves as useful robustness check to make sure that the FG shock is not confused with 
unconventional balance sheet-based instruments. The identifying restrictions used in the expanded model are summarized in Table 3.

Table 3

Identification restrictions in the expanded model

\begin{tabular}{lccccccc}
\hline Shock & $\begin{array}{l}\text { Real } \\
\text { GDP }\end{array}$ & $\begin{array}{c}\text { Core } \\
\text { HICP }\end{array}$ & $\begin{array}{c}\text { 3-month } \\
\text { EURIBOR }\end{array}$ & $\begin{array}{c}\text { 3-month } \\
\text { EURIBOR } \\
\text { 1-year forward rate }\end{array}$ & $\begin{array}{r}\text { EUR/USD } \\
\text { Dow Jones } \\
\text { Euro } \\
\text { Stoxx 50 }\end{array}$ & $\begin{array}{c}10 \text {-year } \\
\text { bond } \\
\text { yields }\end{array}$ & $\begin{array}{c}\text { Securities } \\
\text { held by the } \\
\text { Eurosystem }\end{array}$ \\
\hline Monetary policy & + & + & - & & - & + & 0 \\
FG & + & + & 0 & - & - & + & 0 \\
APP & + & + & 0 & & - & + & - \\
\hline
\end{tabular}

\section{RESULTS}

We start our analysis of the ECB's FG macroeconomic impact with our baseline results from the SVAR with constant parameters and volatility as well as an extension with SV. Figure 1 shows the impulse response functions of the euro area macroeconomic variables in response to the FG shock, scaled to yield a 5 bps drop in the forward rate ${ }^{1}$. Our event study in Appendix A.2 shows that the ECB's FG decreased interest rate expectations to a similar extent when the policy was first officially announced on 4 July 2013. Similar results are also reported in Andrade and Ferroni (2018). The vertical axis is expressed in percent, while the horizontal one shows the number of months since the shock. In general, the results from the two models are similar, both quantitatively and qualitatively. However, our preferred specification is the one with SV since the impulse response functions of real GDP and core HICP are smoother and more hump-shaped, and the subsequent robustness checks in the next section are related to this specification. ${ }^{2}$ Still, the estimated peak effects on both output and prices are largely similar from both specifications, with real GDP and core HICP receiving a $0.09 \%-0.12 \%$ and $0.035 \%$ boost from lower interest rate expectations caused by the ECB's FG respectively.

Thus, our baseline results suggest that the ECB's FG on the future interest path has been an effective policy tool for managing expectations of economic agents and improving the macroeconomic conditions in the euro area. Besides, the results seem intuitive and do not exhibit the "FG puzzle", inherent in standard New Keynesian DSGE models, as the estimated effects do not seem particularly large (see Del Negro et al. (2012) and Christoffel et al. (2018) for a detailed discussion). On top of that, our estimates are in the ballpark of the ECB staff estimates (see Rostagno et al. (2019)).

Next, we employ the expanded model to study the interaction of FG with asset purchases and make sure that the FG shock is not mixed up with other unconventional tools employed by the ECB. For the expanded version, we consider a model with SV, and the results are shown in Figure 2. The results confirm that our identification strategy effectively isolates the FG shock as it is orthogonal to the APP shock. This can be inferred from the fact that the forward rate does not react to the APP shock and the Eurosystem asset holdings do not respond to the FG shock, at least not statistically significantly.

\footnotetext{
${ }^{1}$ Impulse response functions from all models are generated from 15000 Gibbs sampler iterations with the first 10000 discarded as burn-in.

${ }^{2}$ Except the exercise employing narrative sign restrictions.
} 


\section{Figure 1}

\section{Baseline results}
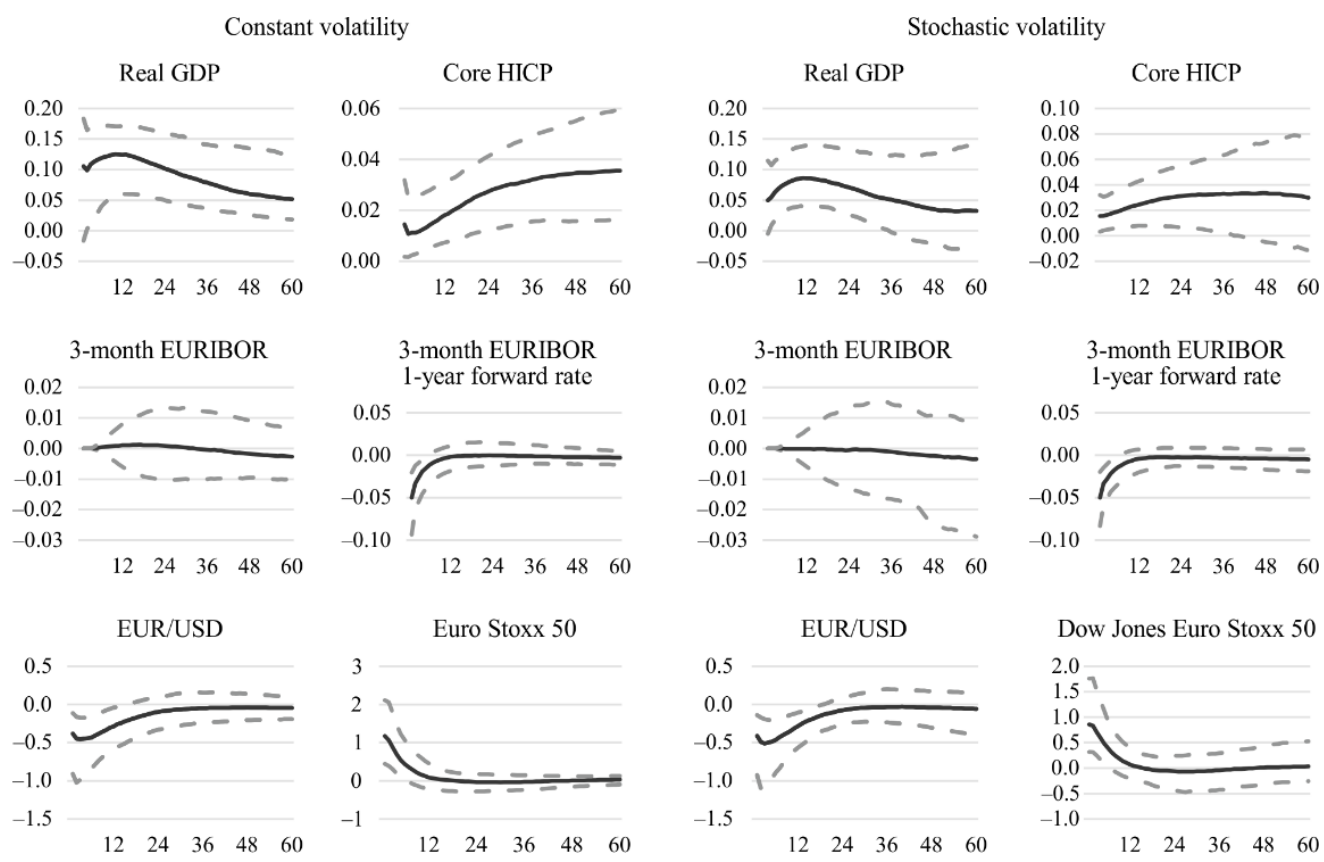

Dow Jones Euro Stoxx 50

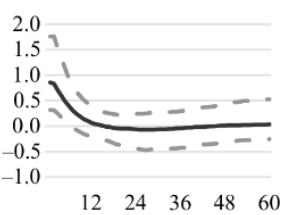

- Median $\quad-\quad-68 \%$ credible sets

Figure 2

\section{Results from the expanded model}

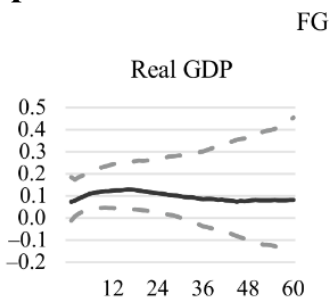

FG shock
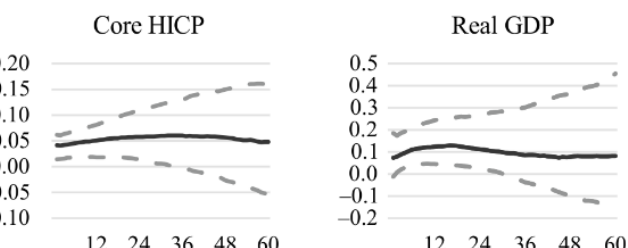

APP shock
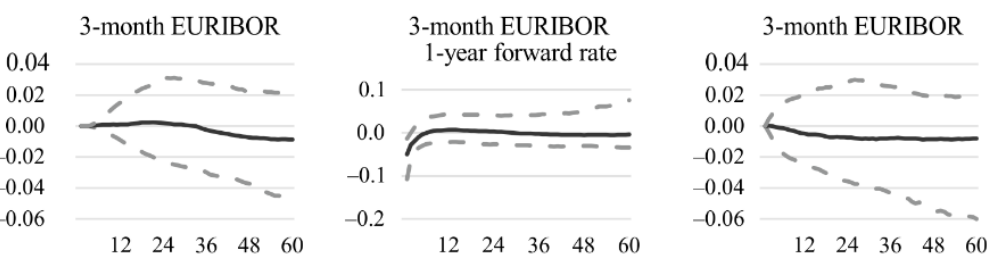

Dow Jones Euro Stoxx 50
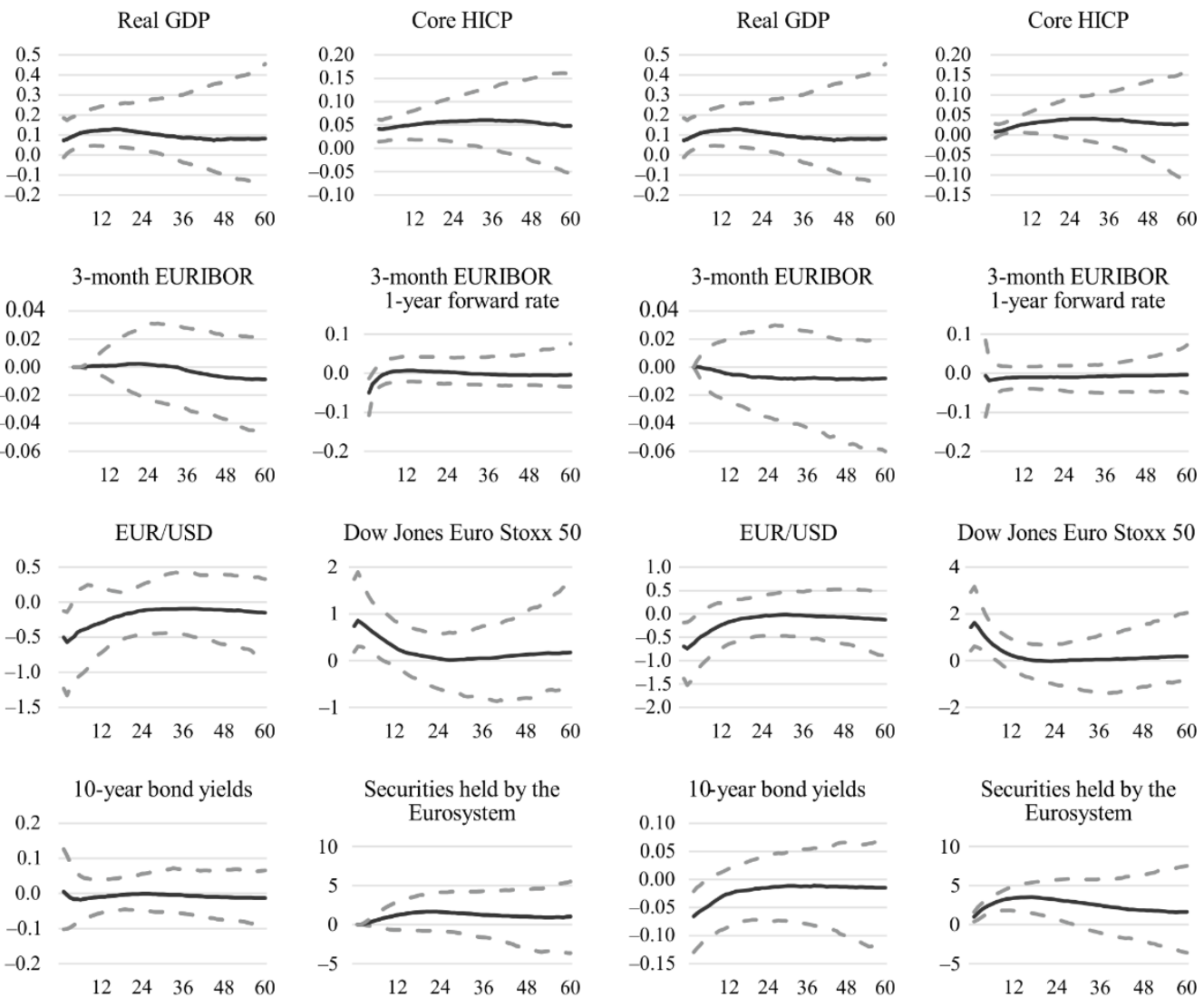

Dow Jones Euro Stoxx 50 4
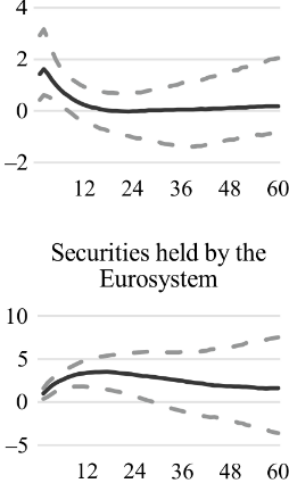

- Median $\quad-\quad-68 \%$ credible sets 
Interestingly though, the findings of this exercise show that the macroeconomic aggregates, i.e. output and prices, display a slightly more pronounced reaction to the FG shock. Precisely, the impact on real GDP is about $45 \%$ higher $(0.13 \%$ vs $0.09 \%$ from the baseline model with SV), while the effect on prices is around $70 \%$ higher $(0.06 \%$ vs $0.035 \%)$ in comparison with the baseline results. These findings suggest that the introduction of the APP considerably enhanced the credibility of FG provided by the ECB. This is in line with Coenen et al. (2017), although we show that FG also generates larger macroeconomic outcomes when the central bank uses it in unison with quantitative easing, while Coenen et al. (2017) only focus on the financial market impact. To bring additional evidence about the interaction of FG with asset purchases, we also revert to our baseline model with SV, but estimate it over the sample when the Eurosystem embarked on the APP, to ascertain that this finding is not coming simply from the fact that we include the Eurosystem's asset holdings in the expanded model.

Figure 3

Results from the baseline model estimated over the APP sample (January 2015-December 2018)
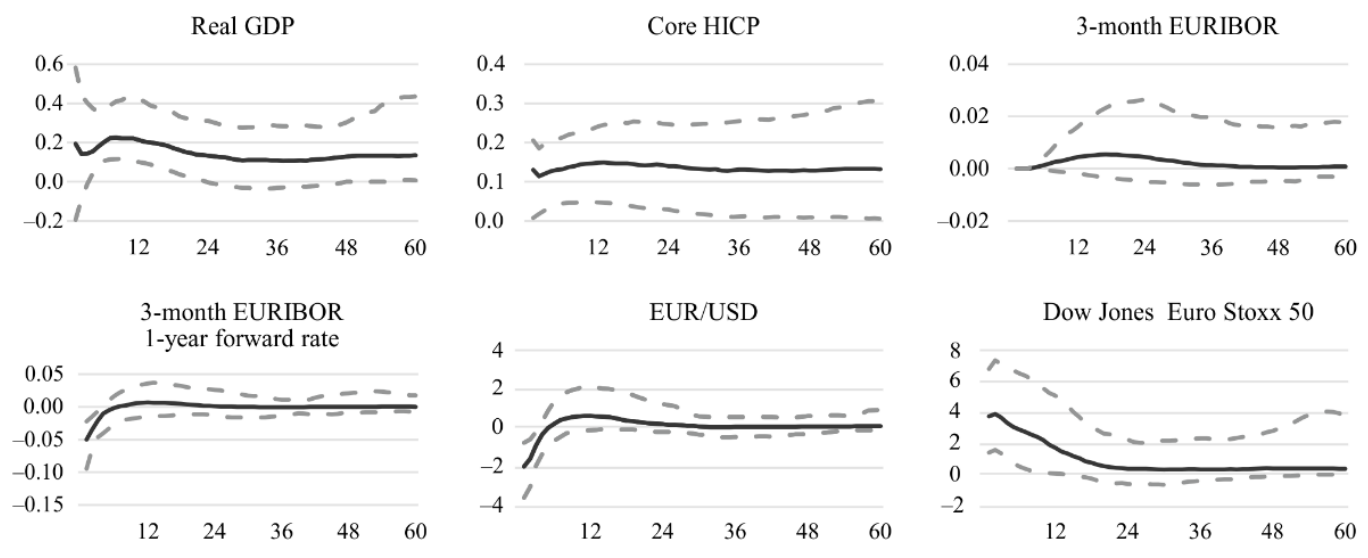

Median $\quad-\quad-68 \%$ credible sets

Results shown in Figure 3 confirm our findings that the ECB's guidance on the future interest rate path was considerably more effective when it had the APP in place, if anything, suggesting an even larger effects than the expanded model.

To further corroborate our findings, we now turn to the results from the TVP-SVARSV model. The results in Figure 4 show that the response of the euro area's economy to the ECB's FG has indeed been non-linear. Results suggest that the response of output to the FG shock has gradually increased since 2015 , i.e. when the ECB also embarked on the APP. While inflation response started to become more pronounced since mid-2013 when the ECB officially started to provide FG. However, the peak impact on inflation can be observed during the period of the APP nonetheless. This leads us to conclude that the FG credibility was considerably enhanced by asset purchases. This is an intuitive finding given the communicated sequencing of measures that policy rates would only be increased after the end of net purchases under the APP. Thus, the APP served as powerful anchor of interest rate expectations and sent a strong signal that policy rates would be kept at low levels. 
Figure 4

Results from the TVP-SVAR-SV
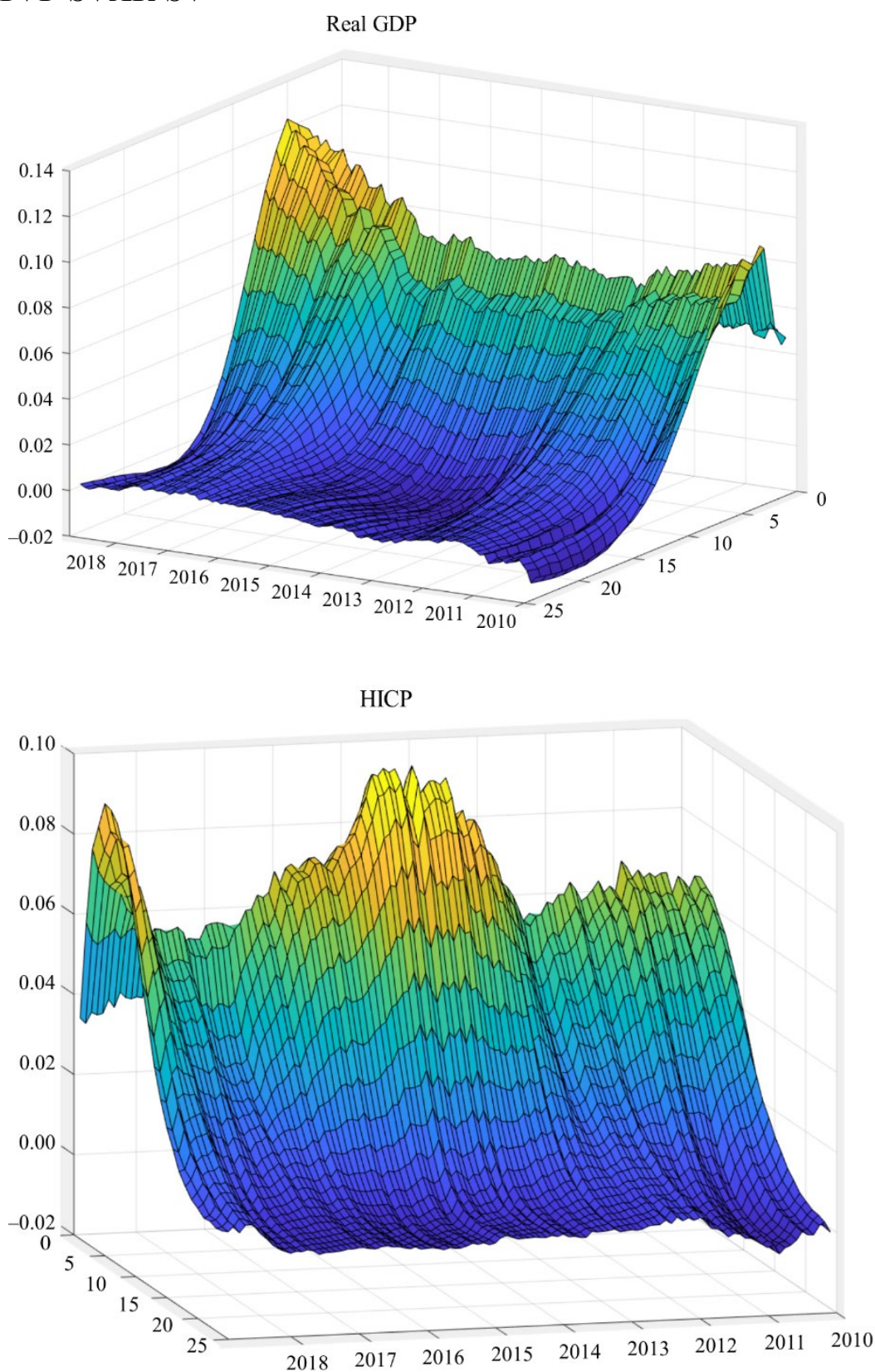

Note. The FG shock in each period has been rescaled to a 5 bps drop in the forward rate, allowing the estimated elasticities to be comparable over time.

Next, we focus on exploring the transmission mechanism of the ECB's FG. To pin down the channels through which FG stimulated real activity, we revert to our baseline model and further expand it with several variables one by one. The findings in Figure 5 show that the ECB announcements on the future interest rate path significantly lowered uncertainty in the euro area financial markets as the CISS index displays a statistically significant downward reaction. It also appears that FG lowered borrowing costs for households and firms as the reaction of lending rate to both types of agents exhibits statistically significant behaviour. Curiously though, the impulse response 
functions of lending itself as well as house prices, while having the expected signs, are surrounded by wide credible sets, rendering them statistically insignificant.

Figure 5

\section{Transmission mechanism}
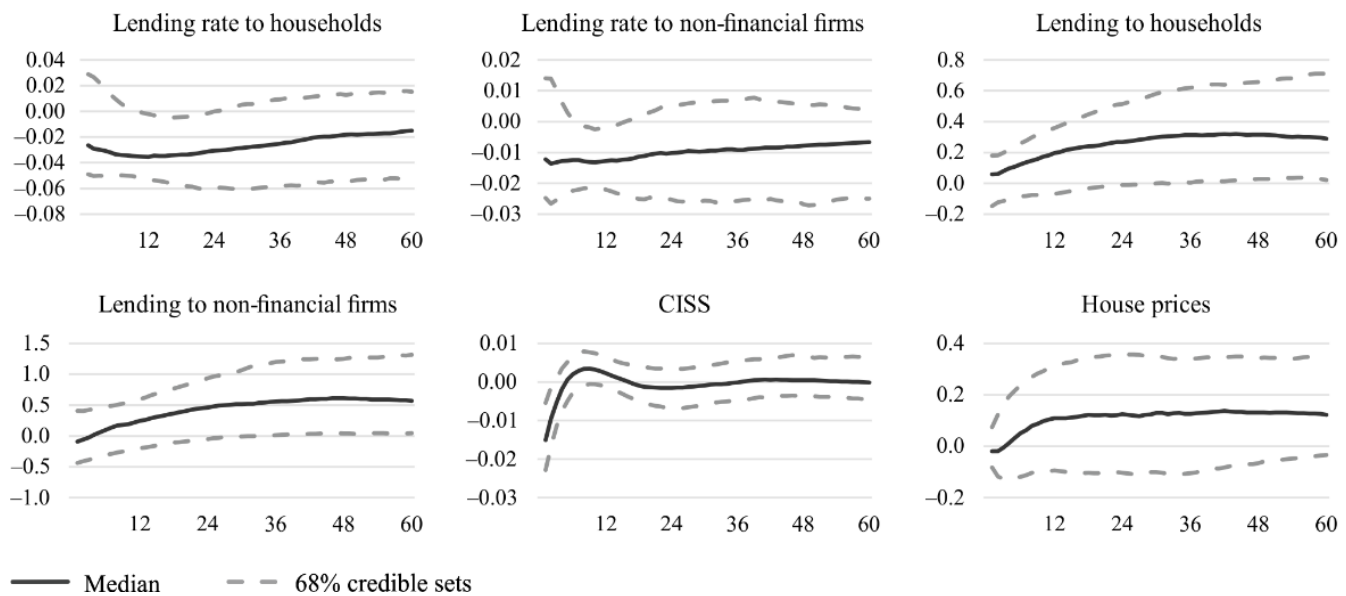

\section{SENSITIVITY ANALYSIS}

In this section, we undertake a number of robustness checks. We start by considering alternative measures of output and price level since the baseline specification includes interpolated real GDP due to our choice to estimate the models using monthly data. To reduce the possibility that our results are driven by a misspecification in the interpolation procedure, we replace monthly real GDP with a "hard" measure of output - industrial production. In addition, we replace core HICP with the overall index of price level.

Figure 6 demonstrates that this is not the case as the impulse response functions of alternative measures display similar effects to the baseline case, both qualitatively and quantitatively.

\section{Figure 6}

\section{Robustness check I: alternative measures of output and price level}
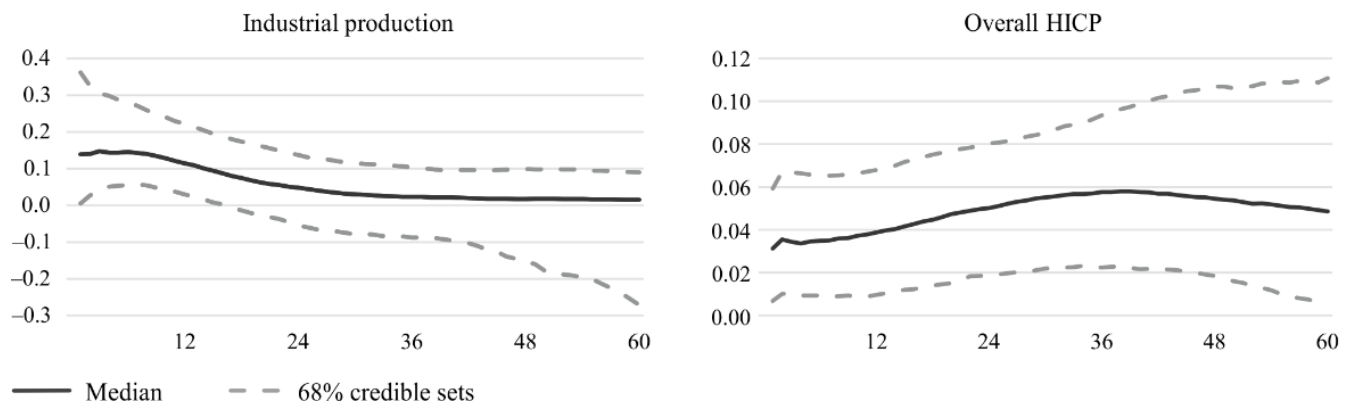

Next, we consider an alternative proxy of interest rate expectations in the euro area derived from survey instead of a market-based information. Precisely, we employ the 4-quarter ahead interest rate forecast from the SPF. We also change the proxy for the short-term interest rate from the 3-month EURIBOR to the MRO rate to match the interest rate which SPF participants are asked to forecast. 
The results in Figure 7 show that the use of survey-based proxy of interest rate expectations yields qualitatively similar results in comparison to the baseline case when we use a market-based proxy, although the estimated peak effects are somewhat higher in this case, suggesting that our baseline estimates of FG effectiveness in the euro area are on the conservative side. However, since we estimate the model with quarterly data when employing the SPF interest rate forecast, we want to make sure that the use of different frequency of data is not the driving factor behind higher estimates of FG impact when using a survey-based proxy.

Figure 7

\section{Robustness check II: survey-based measure of interest rate expectations}

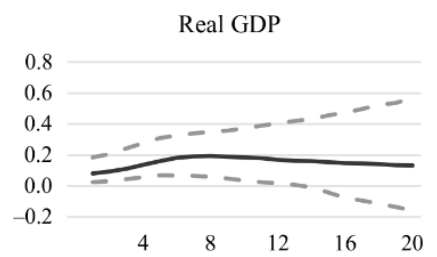

SPF 4-q ahead MRO forecast

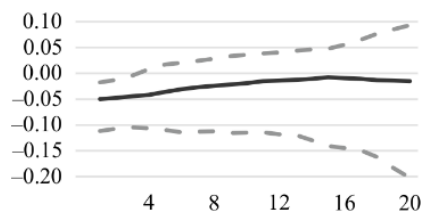

- Median $\quad-\quad-68 \%$ credible sets

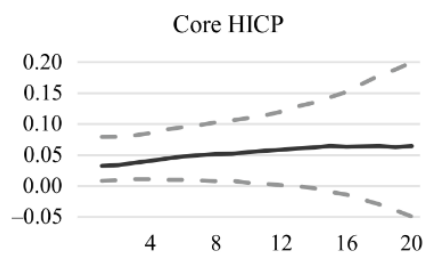

EUR/USD

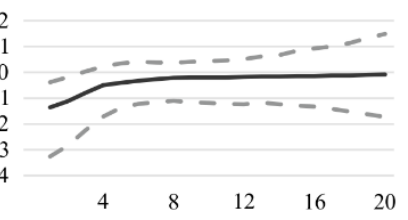

$\begin{array}{llll}4 & 8 & 12 & 16\end{array}$

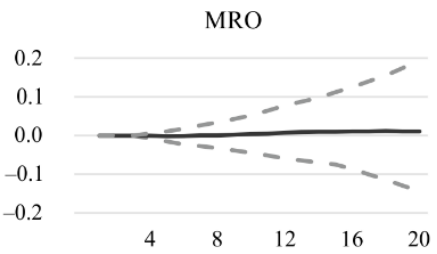

Dow Jones Euro Stoxx 50

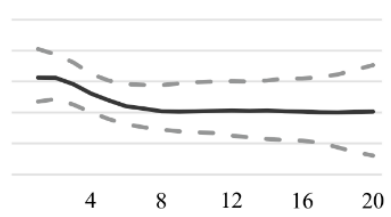

The results in Figure 8 confirm that this is not the case as the results are virtually identical to the baseline case when we use monthly data.

Figure 8

Robustness check III: quarterly data (Q1 2009-Q4 2018)
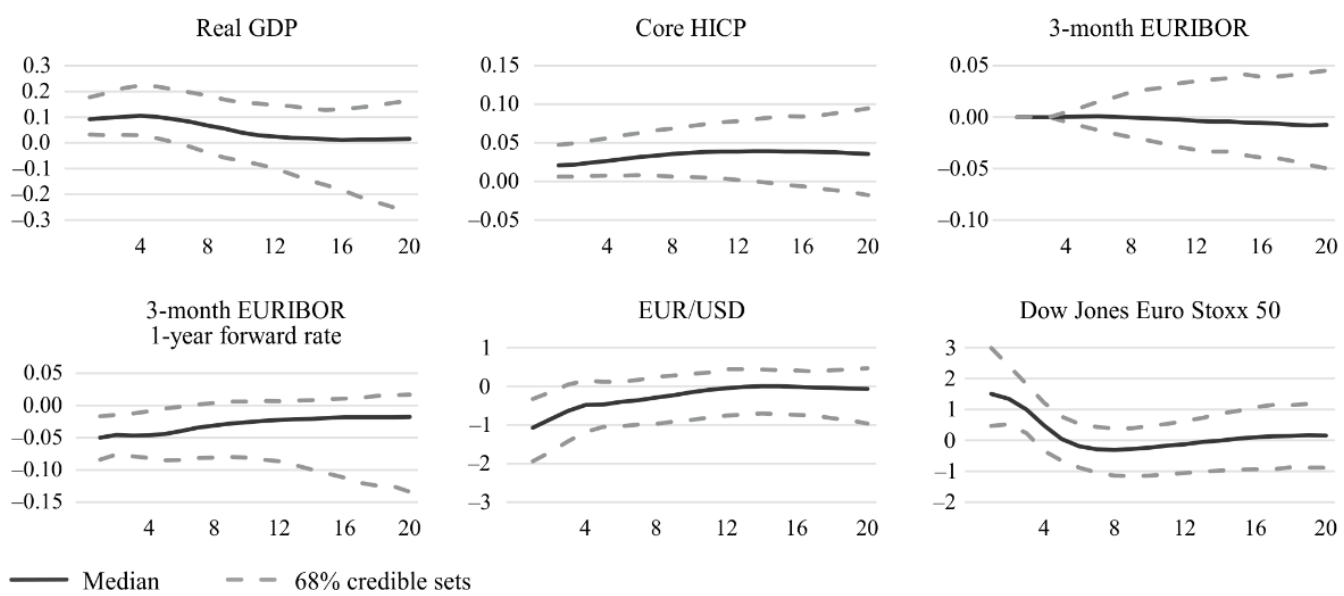

Finally, we test the robustness of our identification scheme. Specifically, in our baseline scheme we choose to restrict both the response of output and prices in reaction to the FG shock, thus the results could be biased due to the use of rather strong prior assumptions. Therefore, we drop both of these restrictions and remain fully agnostic about the impact of FG on real activity and prices. 
Figure 9 suggests that these identifying restrictions indeed play a major role in disentangling the macroeconomic effects of the ECB's FG as the response of both output and inflation is statistically insignificant when these restrictions are dropped. A possible explanation for this outcome, supported by the existing empirical literature as well as our contribution, is as follows: while FG seems to have been an effective policy tool, the macroeconomic effects of it are rather small nonetheless. Accordingly, the use of a smaller set of identifying restrictions might fail to recover the structural FG shock. Fortunately, Antolin-Diaz and Rubio-Ramírez (2018) have recently developed an algorithm allowing to constrain the structural shocks identified via sign restrictions with additional information about the timing of the shock. Therefore, we employ their narrative sign restriction approach to recover the structural FG shock, using narrative information about one event - the official announcement of FG in July 2013, which significantly lowered interest rate expectations in the euro area, i.e. an expansionary FG shock took place. To ensure the robustness of our results, we remain agnostic about the impact on output and prices. Results from this exercise, shown in Figure 10, suggest that FG macroeconomic effects are similar to our baseline estimates, indicating that the identification via narrative sign restrictions successfully recovers the structural FG shock even when no identifying restrictions are imposed on output and prices. The findings of this exercise also justify the restrictions on macroeconomic variables in the baseline scheme when identification is performed via the standard sign and zero restrictions approach.

Figure 9

Robustness check IV: dropping the restrictions on output and price level
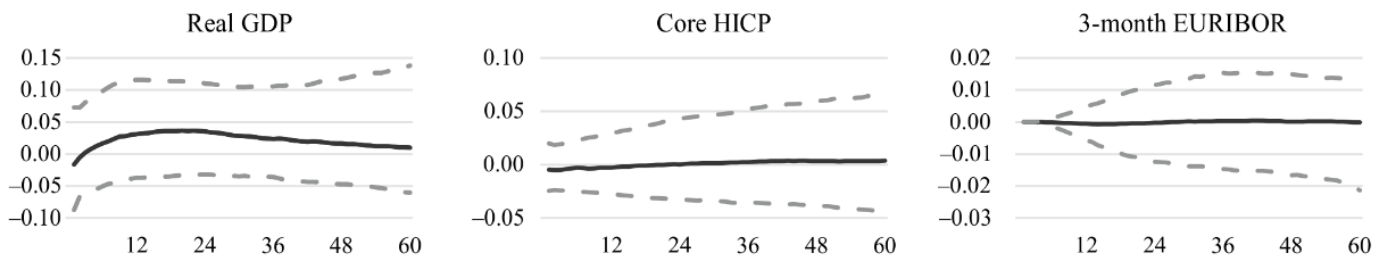

3-month EURIBOR 1-year forward rate
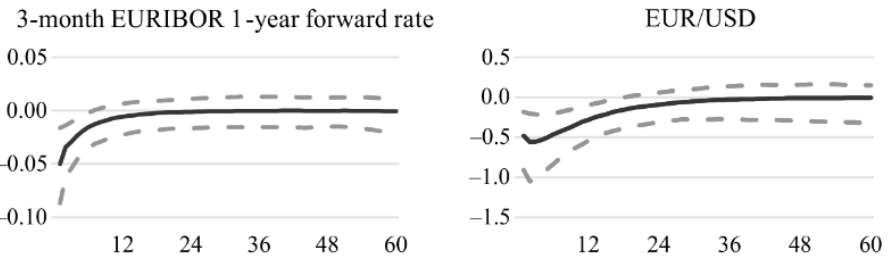

Dow Jones Euro Stoxx 50
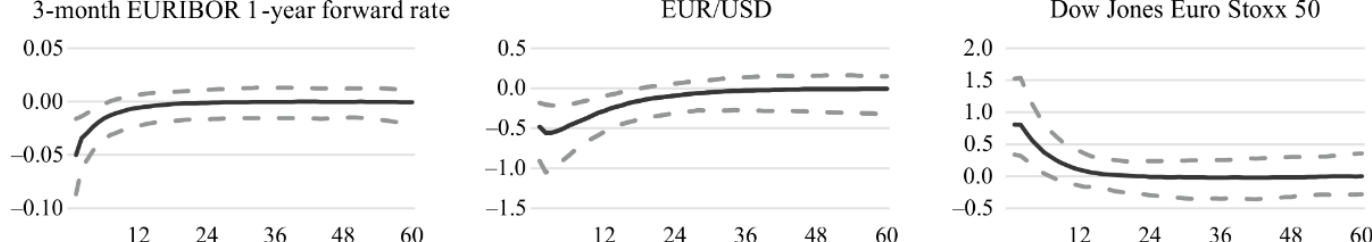

- Median $\quad-\quad-68 \%$ credible sets 
Figure 10

\section{Robustness check V: identification via narrative sign restrictions}
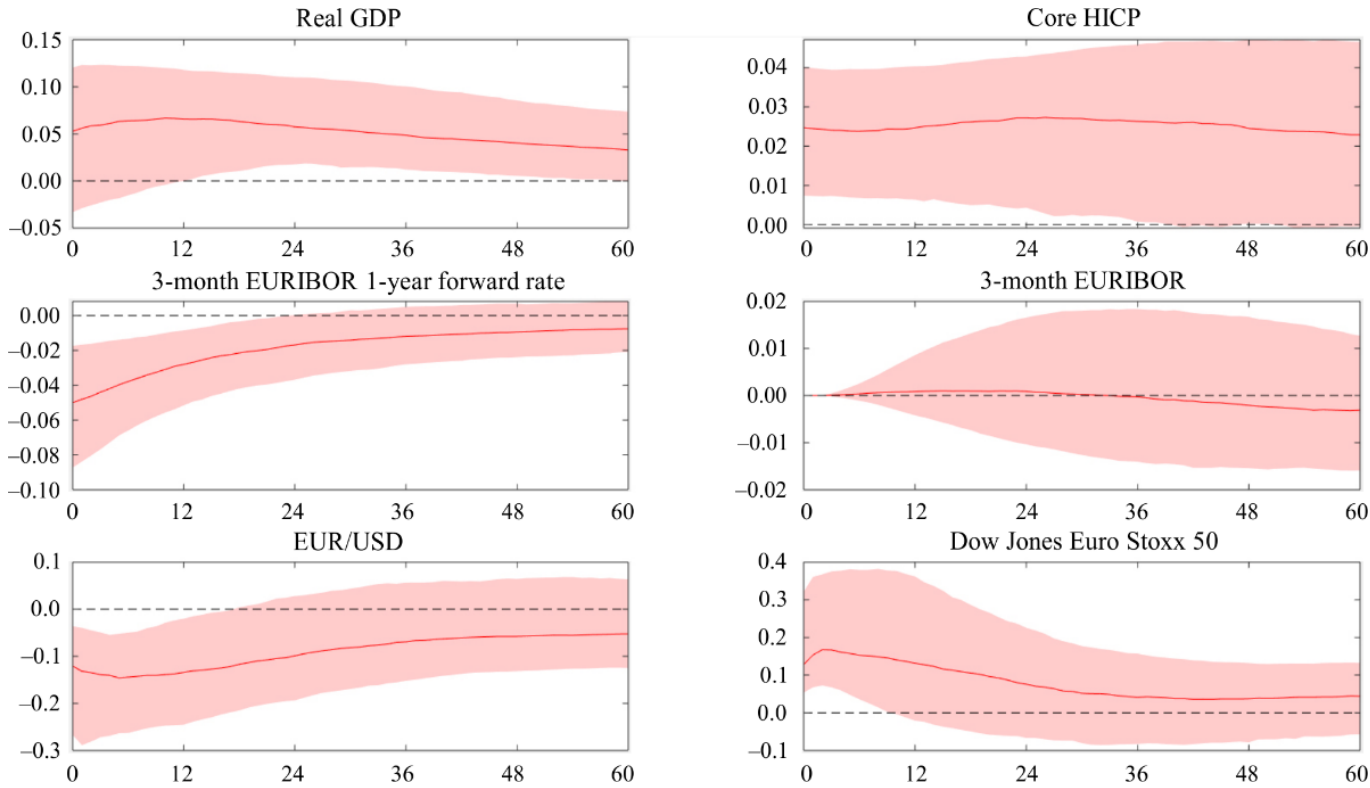

Note. The solid line shows the posterior median, while the shaded area denotes the $68 \%$ credible sets.

\section{CONCLUSIONS}

We have employed a battery of SVARs with both constant and time-varying parameters and/or the covariance matrix and performed identification via both traditional sign and zero restrictions of Arias et al. (2014) and narrative sign restrictions of Antolin-Diaz and Rubio-Ramírez (2018) to trace out the macroeconomic outcomes of the ECB's FG.

Our findings suggest that the ECB's FG on interest rates has been an effective policy tool as the announcement causing a 5 bps drop in interest rate expectations increases the euro area output by $0.09 \%-0.12 \%$ and price level by $0.035 \%$. Regarding the transmission mechanism, we find that the ECB announcements on the future interest rate path significantly lowered uncertainty in the euro area financial markets as well as borrowing costs for both households and firms. However, multiple evidence suggests that the introduction of the APP in 2015 considerably enhanced the FG credibility as its macroeconomic impact has been at least $50 \%$ higher. This is an intuitive finding given the communicated sequencing of measures that policy rates would only be increased after the end of net purchases under the APP. Thus, our findings give empirical proof to the ECB's design of these unconventional tools as mutually reinforcing.

However, while our results suggest that FG has been an effective policy option, the estimated macroeconomic effects can be described as relatively modest. Therefore, the results can also be used for calibrating the estimates from DSGE models to overcome the "FG puzzle", inherent in standard New Keynesian models. 


\section{APPENDIX}

\section{A.1 Dataset description and transformations}

Table A.1

\begin{tabular}{|c|c|c|c|c|}
\hline Block & Variable & Description & $\begin{array}{l}\text { Transfor- } \\
\text { mation }\end{array}$ & Data source \\
\hline \multirow[t]{6}{*}{ Baseline model } & Real GDP & $\begin{array}{l}\text { Seasonally adjusted monthly real GDP index for the } \\
\text { euro area is obtained by performing the Chow-Lin } \\
\text { temporal disaggregation procedure, using industrial } \\
\text { production as an indicator series }(2010=100) \text {. }\end{array}$ & $\ln$ & $\begin{array}{l}\text { Author's } \\
\text { calculations } \\
\text { based on the } \\
\text { Eurostat data }\end{array}$ \\
\hline & Core HICP & $\begin{array}{l}\text { Seasonally adjusted all-items (excluding energy and } \\
\text { food) HICP }(2010=100) \text {. }\end{array}$ & $\ln$ & $\mathrm{ECB}$ \\
\hline & $\begin{array}{l}\text { Dow Jones } \\
\text { Euro Stoxx } 50\end{array}$ & Dow Jones Euro Stoxx 50 price index. & $\ln$ & ECB \\
\hline & EUR/USD & Monthly average value of the euro per US dollar. & $\ln$ & Eurostat \\
\hline & $\begin{array}{l}3 \text {-month } \\
\text { EURIBOR }\end{array}$ & Money market interest rate. & Levels & Eurostat \\
\hline & $\begin{array}{l}\text { 3-month } \\
\text { EURIBOR } \\
1 \text {-year } \\
\text { forward rate }\end{array}$ & 1-year ahead interest rate expectations. & Levels & Bloomberg \\
\hline \multirow[t]{2}{*}{ Expanded model } & $\begin{array}{l}10 \text {-year } \\
\text { bond yields }\end{array}$ & 10-year government benchmark bond yields. & Levels & ECB \\
\hline & $\begin{array}{l}\text { Securities held } \\
\text { by the } \\
\text { Eurosystem }\end{array}$ & $\begin{array}{l}\text { Securities of euro area residents denominated in euro } \\
\text { held by the Eurosystem scaled by } 2015 \text { nominal GDP. }\end{array}$ & $\ln$ & $\begin{array}{l}\text { Author's } \\
\text { calculations } \\
\text { based on the ECB } \\
\text { and Eurostat data }\end{array}$ \\
\hline \multirow[t]{6}{*}{ TVP-SVAR-SV } & Real GDP & $\begin{array}{l}\text { Annual rate of change (YOY growth) in seasonally } \\
\text { adjusted monthly real GDP index. }\end{array}$ & Levels & $\begin{array}{l}\text { Author's } \\
\text { calculations } \\
\text { based on the } \\
\text { Eurostat data }\end{array}$ \\
\hline & $\mathrm{HICP}$ & $\begin{array}{l}\text { Annual rate of change (YOY growth) in seasonally } \\
\text { adjusted all-items HICP. }\end{array}$ & Levels & ECB \\
\hline & $\begin{array}{l}\text { Dow Jones } \\
\text { Euro Stoxx } 50\end{array}$ & $\begin{array}{l}\text { Annual rate of change (YOY growth) in Dow Jones } \\
\text { Euro Stoxx } 50 \text { price index. }\end{array}$ & Levels & ECB \\
\hline & EUR/USD & Monthly average value of the euro per US dollar. & $\ln$ & Eurostat \\
\hline & $\begin{array}{l}3 \text {-month } \\
\text { EURIBOR }\end{array}$ & Money market interest rate. & Levels & Eurostat \\
\hline & $\begin{array}{l}3 \text {-month } \\
\text { EURIBOR } \\
1 \text {-year forward } \\
\text { rate }\end{array}$ & 1-year ahead interest rate expectations. & Levels & Bloomberg \\
\hline
\end{tabular}


Table A.1 (cont.)

\begin{tabular}{|c|c|c|c|c|}
\hline Block & Variable & Description & $\begin{array}{l}\text { Transfor- } \\
\text { mation }\end{array}$ & Data source \\
\hline \multirow{6}{*}{$\begin{array}{l}\text { Transmission } \\
\text { mechanism }\end{array}$} & CISS & Composite Indicator of Systemic Stress. & Levels & $\mathrm{ECB}$ \\
\hline & House prices & $\begin{array}{l}\text { Real residential property prices }(2010=100) \text {. } \\
\text { Monthly series are obtained by performing the } \\
\text { Chow-Lin temporal disaggregation procedure. }\end{array}$ & $\ln$ & BIS \\
\hline & $\begin{array}{l}\text { Lending to } \\
\text { non-financial } \\
\text { firms }\end{array}$ & $\begin{array}{l}\text { Loans to non-financial corporations. Outstanding } \\
\text { amounts at the end of the period (stocks; total } \\
\text { maturity). }\end{array}$ & $\ln$ & ECB \\
\hline & $\begin{array}{l}\text { Lending to } \\
\text { households }\end{array}$ & $\begin{array}{l}\text { Loans to households and NPISHs. Outstanding } \\
\text { amounts at the end of the period (stocks; total } \\
\text { maturity). }\end{array}$ & $\ln$ & ECB \\
\hline & \multicolumn{2}{|c|}{$\begin{array}{l}\text { Lending rate to Annualised agreed rate/narrowly defined effective rate } \\
\text { non-financial for loans to non-financial corporations. } \\
\text { firms }\end{array}$} & Levels & ECB \\
\hline & $\begin{array}{l}\text { Lending rate to } \\
\text { households }\end{array}$ & $\begin{array}{l}\text { Annualised agreed rate/narrowly defined effective rate } \\
\text { for loans to households and NPISHs for house } \\
\text { purchase. }\end{array}$ & Levels & $\mathrm{ECB}$ \\
\hline \multirow[t]{4}{*}{$\begin{array}{l}\text { Robustness } \\
\text { checks }\end{array}$} & $\begin{array}{l}\text { Industrial } \\
\text { production }\end{array}$ & $\begin{array}{l}\text { Seasonally adjusted industrial production index } \\
(2010=100) \text {. }\end{array}$ & $\ln$ & Eurostat \\
\hline & $\mathrm{HICP}$ & Seasonally adjusted all-items HICP $(2010=100)$. & $\ln$ & ECB \\
\hline & MRO & Interest rate on the main refinancing operations. & Levels & ECB \\
\hline & \multicolumn{2}{|c|}{$\begin{array}{l}\text { SPF } 4 \text { Q ahead 1-year ahead interest rate forecasts from SPF. } \\
\text { MRO forecast }\end{array}$} & Levels & ECB \\
\hline
\end{tabular}

\section{A.2 Event study}

Figure A.1

Impact of the ECB announcements on interest rate expectations

Reaction of 3-month EURIBOR 1-year forward rate after the Governing Council of the ECB on 4 July 2013

0.21

0.20

0.19
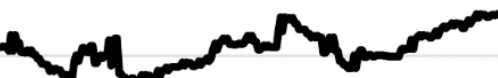

0.18

0.17

0.16

0.15

0.14

0.13

0.12

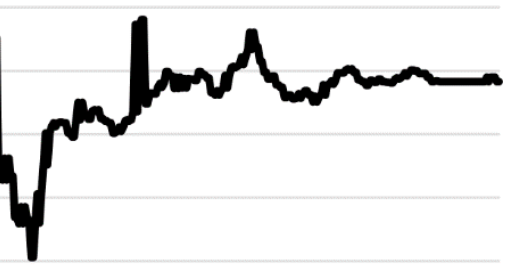

In order to arrive at a meaningful shock size for scaling the impulse response functions to FG disturbance, we undertake an event study approach, using intraday data of 3-month EURIBOR 1-year forward rate to investigate the impact of the ECB's FG 
announcements on interest rate expectations in the euro area. Precisely, we study the reaction of interest rate expectations on 4 July 2013 when the ECB started to provide guidance on the future interest rate path. Figure A.1 shows that the market reacted sharply to this announcement as the 1-year forward rate dropped by approximately 5 bps after the press release and press conference. Therefore, we calibrate the FG shock to yield a 5 bps drop in the forward rate. 


\section{BIBLIOGRAPHY}

ADAM, Klaus, BILLI, Roberto M. (2006). Optimal Monetary Policy under Commitment with a Zero Bound on Nominal Interest Rates. Journal of Money, Credit and Banking, vol. 38, issue 7, October 2006, pp. 1877-1905.

ADAM, Klaus, BILLI, Roberto M. (2007). Discretionary Monetary Policy and the Zero Lower Bound on Nominal Interest Rates. Journal of Monetary Economics, vol. 54, issue 3, April 2007, pp. 728-752.

ALTAVILLA, Carlo, BRUGNOLINI, Luca, GÜRKAYNAK, Refet S., MOTTO, Roberto, RAGUSA, Giuseppe (2019). Measuring Euro Area Monetary Policy. ECB Working Paper, No. 2281, May 2019. 56 p.

ANDRADE, Philippe, FERRONI, Filippo (2018). Delphic and Odyssean Monetary Policy Shocks: Evidence from the Euro Area. Federal Reserve Bank of Chicago Working Paper, No. 2018-12, 26 June 2018. 47 p.

ANTOLIN-DIAZ, Juan, RUBIO-RAMÍREZ, Juan Francisco (2018). Narrative Sign Restrictions for SVARs. American Economic Review, vol. 108, No. 10, October 2018, pp. 2802-2829.

ARIAS, Jonas E., RUBIO-RAMÍREZ, Juan Francisco, WAGGONER, Daniel F. (2014). Inference Based on SVAR Identified with Sign and Zero Restrictions: Theory and Applications. CEPR Discussion Paper, No. DP9796, January 2014. 74 p.

BLINDER, Alan, EHRMANN, Michael, DE HAAN, Jakob, JANSEN, David-Jan (2017). Necessity as the Mother of Invention: Monetary Policy After the Crisis. Economic Policy, vol. 32, issue 92, October 2017, pp. 707-755.

CAMPBELL, Jeffrey R., EVANS, Charles L., FISHER, Jonas D. M., JUSTINIANO, Alejandro (2012). Macroeconomic Effects of Federal Reserve Forward Guidance. Brookings Papers on Economic Activity, vol. 43, issue 1, Spring 2012, pp. 1-80.

CHRISTOFFEL, Kai, MAZELIS, Falk, MONTES-GALDÓN, Carlos (2018). Forward Guidance Redux. Mimeo.

COENEN, Günter, EHRMANN, Michael, GABALLO, Gaetano, HOFFMANN, Peter, NAKOV, Anton, NARDELLI, Stefano, PERSSON, Eric, STRASSER, Georg (2017). Communication of Monetary Policy in Unconventional Times. ECB Discussion Paper, No. 2080, June 2017. 46 p.

COGLEY, Timothy, SARGENT, Thomas J. (2005). Drift and Volatilities: Monetary Policies and Outcomes in the Post WWII U.S. Review of Economic Dynamics, vol. 8, issue 2, April 2005, pp. 262-302.

D'AMICO, Stefania, KING, Thomas B. (2015). What Does Anticipated Monetary Policy Do? Federal Reserve Bank of Chicago Working Paper, No. WP-2015-10, December 2015. $66 \mathrm{p}$.

DEL NEGRO, Marco, GIANNONI, Marc, PATTERSON, Christina (2012). The Forward Guidance Puzzle. Federal Reserve Bank of New York Staff Report, No. 574, October 2012 (revised December 2015). 32 p. 
DIEPPE, Alistair, LEGRAND, Romain, VAN ROYE, Björn (2016). The BEAR Toolbox. ECB Working Paper, No. 1934, July 2016. 291 p.

GAMBETTI, Luca, MUSSO, Alberto (2017). The Macroeconomic Impact of the ECB's Expanded Asset Purchase Programme (APP). ECB Working Paper, No. 2075, June 2017. $42 \mathrm{p}$.

JACQUIER, Eric, POLSON, Nicholas G., ROSSI, Peter (1994). Bayesian Analysis of Stochastic Volatility Models. Journal of Business and Economic Statistics, vol. 12, issue 4, pp. 371-389.

JAROCIŃSKI, Marek, KARADI, Peter (2018). Deconstructing Monetary Policy Surprises: The Role of Information Shocks. ECB Working Paper, No. 2133, February 2018 (revised June 2018). 63 p.

MERTENS, Karel, RAVN, Morten O. (2013). The Dynamic Effects of Personal and Corporate Income Tax Changes in the United States. American Economic Review, vol. 103, No. 4, June 2013, pp. 1212-1247.

MOESSNER, Richhild (2013). Effects of Explicit FOMC Policy Rate Guidance on Interest Rate Expectations. Economics Letters, vol. 121, issue 2, pp. 170-173.

MOESSNER, Richhild (2015). Reactions of Real Yields and Inflation Expectations to Forward Guidance in the United States. Applied Economics, vol. 47, issue 26, June 2015, pp. 2671-2682.

MOESSNER, Richhild, JANSEN, David-Jan, DE HAAN, Jakob (2017). Communication about Future Policy Rates in Theory and Practice: A Survey. Journal of Economic Surveys, vol. 31, issue 3, pp. 678-711.

NAKOV, Anton A. (2008). Optimal and Simple Monetary Policy Rules with Zero Floor on the Nominal Interest Rate. International Journal of Central Banking, vol. 4, issue 2, June 2007, pp. 73-127.

PRIMICERI, Giorgio E. (2005). Time Varying Structural Vector Autoregressions and Monetary Policy. The Review of Economic Studies, vol. 72, issue 3, July 2005, pp. 821-852.

ROSTAGNO, Massimo, ALTAVILlA, Carlo, CARBONI, Giacomo, LEMKE, Wolfgang, MOTTO, Roberto, SAINT-GUILHEM, Arthur, YIANGOU, Jonathan (2019). A Tale of Two Decades: The ECB's Monetary Policy at 20. ECB Working Paper (forthcoming). Results retrieved from:

https://www.ecb.europa.eu/press/key/date/2019/html/ecb.sp190701 0clfa3c8fc.en.html.

RUBIO-RAMÍREZ, Juan Francisco, WAGGONER, Daniel F., ZHA, Tao (2010). Structural Vector Autoregressions: Theory of Identification and Algorithms for Inference. The Review of Economic Studies, vol. 77, No. 2, April 2010, pp. 665-696.

STOCK, James H., WATSON, Mark W. (2012). Disentangling the Channels of the 2007-09 Recession. Brookings Papers on Economic Activity, vol. 43, issue 1, Spring 2012, pp. 81-156.

WOODFORD, Michael (2013). Forward Guidance by Inflation-Targeting Central Banks. CEPR Discussion Paper, No. DP9722, November 2013. 56 p. 